\title{
PERAN KEPALA DESA DALAM PELAKSANAAN PEMBANGUNAN DI DESA PEKIK NYARING KECAMATAN PONDOK KELAPA KABUPATEN BENGKULU TENGAH
}

\section{Oleh:}

Marsidi $^{1}$

\begin{abstract}
ABSTRAKSI
Peran Kepala Desa dalam pembangunan desa sangat penting karena Kepala Desa itu sebagai penggerak pembangunan desa apabila Kepala Desa tidak melaksanakan perannya dengan baik maka pembangunan desa tidak akan terlaksanan secara efektif dan efisien. Penelitian ini bertujuan untuk bagaimana peran kepala desa dalam pelaksanaan pembangunan di Desa Pekik Nyaring Kecamatan Pondok Kelapa Kabupaten Bengkulu Tengah. Untuk menjawab dari tujuan yang dimaksud maka pendekatan penelitian yang digunakan yaitu deskriptif kualitatif. Hasil penelitian menunjukkan Kepala Desa sebagi pembina masyarakat hanya memberi dorongan proses pembangunan ke arah yang lebih baik dengan memanfaatkan kondisi sektor perekonomian di masyarakat mengingat lokasi Desa Pekik Nyaring adalah basis perekonomian yang banyak dibidang perkebunan dan pedagang. Hal ini mengakibatkan perekonomian Desa menjadi lebih baik dari sebelumnya sehingga berimbas kepada kesejahteraan masyarakat yang baik. Sedangkan untuk Pelayanan publik yang diberikan oleh pemerintah Desa bisa dikatakan telah memuaskan warga sehingga pembangunan yang dilaksanakan di Desa Pekik Nyaring dapat terlaksana dengan lancar karena adanya dukungan dari seluruh masyarakat. Pelayanan yang diberikan oleh pemerintah Desa kepada masyarakat dalam hal ini berupa pengurusan surat-surat yang sudah tidak ada biaya patokan dan waktu lama yang bisa merugikan. Sedangkan untuk faktor pendukung peran kepala desa yaitu faktor partisipasi dan hubunganan antar aparatur. Sedangkan faktor penghambatnya yaitu faktor Sumber daya manusia, dan sarana prasarana yang tersedia.
\end{abstract}

Kata Kunci : Peran Kepala Desa, Pembangunan Desa, Bengkulu Tengah

\footnotetext{
${ }^{1}$ Dosen Tetap Prodi Ilmu Administrasi Negara STIA Bengkulu
} 


\section{A. Pendahuluan}

Otonomi desa bahwa desa mampu berinisiatif dan berkreativitas untuk menjalankan pemerintahannya sendiri serta menumbuhkan demokratisasi masyarakat dalam pembangunan, sehingga desa atau setingkat desa memiliki ruang gerak yang luas dalam melaksanakan pembangunan, karena tidak terbebani lagi dengan programprogram pembangunan dari kabupaten/kota, provinsi maupun pemerintah pusat.

Undang-undang Nomor 6 tahun 2014 tentang Desa pada pasal 26 mengatakan Kepala Desa bertugas menyelenggarakan Pemerintahan Desa, melaksanakan Pembangunan Desa, pembinaan kemasyarakatan Desa, dan pemberdayaan masyarakat Desa. Berdasarkan undangundang tersebut jelas diamanatkan kepada kepala desa untuk menyelenggarakan pembangunan Desa, tentunya dengan segala kapasitas yang diberikan kepadanya salah satunya menggunakan partisipasi masyarakat.

Pelaksanaan pembangunan desa, sesuai dengan Peraturan Menteri Dalam Negeri Nomor 114 Tahun 2014 Tentang Pedoman Pembangunan Desa, sangat jelas disebutkan dalam pasal 1 ayat 9 bahwa: Pembangunan Desa adalah upaya peningkatan kualitas hidup dan kehidupan untuk sebesar-besarnya kesejahteraan masyarakat Desa. Selajutnya dalam asas pengeleloaan keuangan desa pasal 2 ayat 1 dan 2 disebutkan bahwa: pemerintah desa menyusun perencanaan Pembangunan Desa sesuai dengan kewenangannya dengan mengacu pada perencanaan pembangunan Kabupaten/Kota, pembangunan desa sebagaimana dimaksud pada ayat (1) dilaksanakan oleh Pemerintah Desa dengan melibatkan seluruh masyarakat desa dengan semangat gotong royong.

Dalam kaitannya dengan Desa Pekik Nyaring Kecamatan Pondok Kelapa, berdasarkan hasil survey awal peneliti menemukan fenomena-fenomena bahwa: pertama, sampai saat ini belum ada konsep/model pembangunan desa yang dapat menjadi solusi secara optimal dalam upaya pengentasan kemiskinan di desa. Kedua, pembangunan desa yang dilaksanakan bersifat sektoral, yang hanya akan memberikan solusi secara parsial juga dan dengan waktu yang bersifat temporer, sehingga tidak ada jaminan kelangsungan program pembangunan tersebut. Ketiga, sumber daya manusia di desa, baik aparat maupun masyarakatnya memberikan kontribusi besar terhadap melambatnya berbagai upaya pelaksanaan pembangunan desa itu sendiri, keterbatasan sumber pendanaan, baik dari desa maupun dari Kabupaten, Provinsi dan Nasional, merupakan faktor utama lain yang menyebabkan lambatnya proses pembangunan desa.

Berdasarkan uraian latar belakang serta masalah-masalah penelitian, maka rumusan masalah dalam penelitian ini adalah: bagaimana peran kepala desa dalam pelaksanaan pembangunan di Desa Pekik Nyaring Kecamatan Pondok Kelapa Kabupaten Bengkulu Tengah?

Adapun tujuan dari penelitian ini adalah untuk mengetahui peran Kepala Desa dalam pelaksanaan pembangunan di Desa Pekik Nyaring Kecamatan Pondok Kelapa Kabupaten Bengkulu Tengah.

\section{B. Metode Penelitian}

Penelitian ini adalah penelitian deskripstif kualitatif. Teknik pengumpulan data dilakukan dengan metode wawancara, observasi, dan dokumentasi. Lokasi penelitian bertempat di Desa Pekik Nyaring Kecamatan Pondok Kelapa Kabupaten Bengkulu Tengah.

Fokus penelitian ini yaitu : Peran Kepala Desa dan Perangkat Desa dalam menjalankan tugas sebagai penyelenggara pemerintahan tingkat Desa, sebagaimana diatur dalam Undang-Undang Nomor 6 Tahun 2014 Tentang Desa yakni tugas kepala desa khususnya dalam pelaksanaan Pembangunan Pembinaan dan pemberdayaan masyarakat.

C. Hasil Penelitian dan Pembahasan

1. Peran Kepala Desa dalam Pembangunan Desa Pekik Nyaring

a. Peranan Pemerintah Desa dalam Pembangunan Desa

Peranan kepala Desa sebagai pembina Pemerintah Desa sebagi pembina masyarakat hanya berupa memberi dorongan proses pembangunan ke arah lebih baik dengan memanfaatkan kondisi sektor perekonomian di masyarakat mengingat lokasi Desa Pekik Nyaring adalah basis perekonomian yang banyak di bidang perkebunan dan pedagang. Hal ini mengakibatkan perekonomian Desa menjadi lebih baik dari sebelumnya sehingga berimbas kepada kehidupan masyarakat yang sejahtera sudah baik. 


\section{b. Peranan Kepala Desa Sebagai Pelayan Masyarakat}

Pelayanan publik yang diberikan oleh pemerintah Desa bisa dikatakan telah memuaskan warga sehingga pembangunan yang dilaksanakan di Desa Pekik Nyaring dapat terlaksana dengan lancar karena adanya dukungan dari seluruh masyarakat. Pelayanan yang diberikan oleh pemerintah Desa kepada masyarakat.

Serta bagaimana Kepala Desa menyelesaikan masalah yang dihadapi masyarakat dan lainnya yang menjadi kebutuhan atau kepentingan masyarakat.

\section{Faktor-faktor yang Mempengaruhi Pelaksanaan Pembangunan Desa \\ a. Partisipasi Masyarakat}

Hasil analisis penelitian yang dilakukan dalam menggali informasi dari lokasi Desa Pekik Nyaring maka ditemukan bahwa partisipasi masyarakat yang baik ini terlihat dengan adanya berbagai perhatian dari masyarakat terhadap semua perkembangan yang ada di lingkup pemerintahan Pekik Nyaring, dan masyarakat sangat respon dan antusias dengan hal tersebut. Tentu saja hal ini sangat mendukung peranan kepala Desa dalam pembangunan.

\section{b. Kerjasama antar Sesama Aparatur}

Kerjasama antara aparatur pemerintah Desa Pekik Nyaring ini tergolong baik. Hal tersebut dapat dilihat dari hubungan yang sangat harmonis antara sesama aparatur Desa, berupa keakraban yang terjadi antar sesama aparat, serta kepatuhan semua aparatur terhadap Kepala Desa. Kesemua ini mengindikasikan apabila terdapat salah seorang pegawai yang yang berhalangan tidak dapat melaksanakan tugasnya di kantor Desa, maka pegawai lain bersedia menggantikan tugas tersebut sehingga pelayanan terhadap masyarakat terlaksana dengan maksimal demi perkembangan yang berarti pembangunan dapat didukung.

\section{c. Sarana dan Prasaran Desa}

Masih kurangnya sarana dan prasarana Kegiatan masyarakat berdemokratis dalam pembangunan dipengaruhi oleh ketersedianya fasilitas atau peralatan, misalnya dalam pertemuan atau rapat akan berjalan lancar jika tersedianya tempat beserta peralatannya. Kurangnya fasilitas sarana dan prasarana sangat menghambat kinerja pemerintah demi terselenggaranya pembangunan. Sarana perhubungan yang kurang memadai ini masih dikeluhkan oleh pemerintah Desa seperti ada jalan yang rusak. Dari sini dapat dilihat bahwa faktor fasilitas atau peralatan yang kurang memadai akan menghambat perkembangan pembangunan di Pekik Nyaring.

\section{d. Kualitas Sumber Daya Aparat}

Kualitas sumber daya manusia aparat pemerintah Desa Pekik Nyaring terbilang cukup rendah. Terlihat dengan masih benyaknya aparat pemerintah Desa Pekik Nyaring yang hanya tamatan SMA dan hal tersebut membuat Kepala Desa selalu memotivasi aparatnya agar melanjutkan studinya ke jenjang lebih tinggi, ada beberapa yang sudah sarjana tapi bukan lulusan Ilmu Sosial dan Politik sehingga mempengaruhi tingkat keterampilan (skill) aparatur yang relatif rendah, masih banyak aparat yang belum bisa mengoperasikan teknologi komputer yang tentu saja dapat menghambat pelayanan di bidang administrasi. Terhambatnya pelayanan kepada masyarakat merupakan hal yang berdampak tidak efisiennya pembangunan di Desa Pekik Nyaring.

\section{Kesimpulan dan Saran}

1. Kesimpulan

Adapun kesimpulan yang dapat

ditarik adalah :

\section{1) Peran Kepala Desa Dalam Pembangunan Desa}

a. Peranan kepala Desa sebagai pembina Pemerintah Desa, sebagi pembina masyarakat hanya berupa memberi dorongan proses pembangunan ke arah lebih baik dengan memanfaatkan kondisi sektor perekonomian di masyarakat mengingat lokasi Desa Pekik Nyaring adalah basis perekonomian yang banyak di bidang perkebunan dan perdagangan. Hal ini mengakibatkan perekonomian Desa menjadi lebih baik dari sebelumnya sehingga berimbas kepada kehidupan masyarakat yang sejahtera sudah baik

b. Pelayanan publik yang diberikan oleh pemerintah Desa bisa dikatakan telah memuaskan warga sehingga pembangunan yang dilaksanakan di Desa Pekik Nyaring dapat terlaksana 
dengan lancar karena adanya dukungan dari seluruh masyarakat.

\section{2) Faktor Pendukung Kepala Desa Dalam Pembangunan Desa}

a. Partisipasi Masyarakat partisipasi masyarakat yang baik ini terlihat dengan adanya berbagai perhatian dari masyarakat terhadap semua perkembangan yang ada di lingkup pemerintahan Pekik Nyaring, dan masyarakat sangat respon dan antusias dengan hal tersebut. Tentu saja hal ini sangat mendukung peranan kepala Desa dalam pembangunan.

b. Kerjasama Antar Aparatur Desa Kerjasama antara aparatur pemerintah Desa Pekik Nyaring ini tergolong baik. Hal tersebut dapat dilihat dari hubungan yang sangat harmonis antara sesama aparatur Desa, berupa keakraban yang terjadi antar sesama aparat, serta kepatuhan semua aparatur terhadap Kepala Desa

\section{3) Faktor Penghambat Kinerja BPPT}

a. Sarana Prasarana

Masih kurangnya sarana dan prasarana kegiatan masyarakat berdemokratis dalam pembangunan dipengaruhi oleh ketersedianya fasilitas atau peralatan, misalnya dalam pertemuan atau rapat akan berjalan lancar jika tersedianya tempat beserta peralatannya. Kurangnya fasilitas sarana dan prasarana sangat menghambat kinerja pemerintah demi terselenggaranya pembangunan.

b. Kualitas SDM

Kualitas sumber daya manusia aparat pemerintah Desa Pekik Nyaring terbilang cukup rendah. Terlihat dengan masih benyaknya aparat pemerintah Desa Pekik Nyaring yang hanya tamatan SMA

\section{Saran}

Saran yang dapat diberikan atas permasalahan di Desa Pekik Nyaring adalah sebagai berikut :

Diperlukan optimalisasi peran kepala desa dalam meningkatan kualitas sumber daya manusia aparat pemerintah yang masih tamatan SMA agar segera melanjutkan studi ke jenjang lebih tinggi dan mengupayakan penguasaan keterampilan (skill) yang handal dan meningkatkan sarana prasarana yang ada di desa seperti sarana pelayanan publik.

\section{DAFTAR PUSTAKA}

Sumber dari Buku :

Atep, Adtya, Barata, 2004, Dasar-dasar Pelayanan Prima, Jakarta : PT. Elex Media Komputindo.

Adisasmita, Rahardjo. 2006. Pembangunan Pedesaan dan Perkotaan. Graha Ilmu. Yogyakarta

Affandi, Anwar dan Setia Hadi. 1996. Perencanaan Pembangunan Wilayah dan Pedesaan. Prisma, Jakarta

Agus, Dwiyanto. 1995. Pelayanan Organisasi Pelayanan Publik. Yogyakarta University Press, Yogyakarta

Amirin, Tatang, M. Drs. 1995. Menyusun Rencana Penelitian. Raja Grafindo Persada, Jakarta

Bayu Suryaningrat. 1976. Pemerintahan dan Administrasi Desa. Yayasan Beringin Korpri Unit Depdagri, Jakarta

Beratha, I Nyoman, Drs. 1991. Pembangunan Desa Berwawasan Lingkungan. Bumi Aksara, Jakarta

Beratha, I Nyoman. 1982. Desa, Masyarakat dan Pembangunan Desa. Ghalia Indonesia, Jakarta

Bintoron, Tjokroamidjojo. 1978. Pengantar Administrasi Pembangunan. LP3ES, Jakarta

Daldjoeni, N dan A. Suyitno. 2004. Pedesaan, Lingkungan dan Pembangunan. Bandung : PT. Alumni.

Sumber Non Buku :

Undang-Undang Nomor 6 Tahun 2014 Tentang Desa

Peraturan Pemerintah Nomor 43 Tahun 2014 Tentang Petunjuk Pelaksanaan UndangUndang Nomor 6 Tahun 2014.

Peraturan Menteri Dalam Negeri Nomor 114 Tahun 2014 Tentang Pedoman Pembangunan Desa 